\title{
The variation in the self-perceived quality of life and health care amongst smokers, passive smokers, ex-smokers and non-smokers in Canada
}

Samy Beshay ${ }^{1 *}$, Hany Beshay ${ }^{2}$

From 4th International Conference for Healthcare and Medical Students (ICHAMS) 2014

Dublin, Ireland. 24-25 October 2014

\section{Background}

In 2012 nearly $20 \%$ of Canadians aged 12 and above had stated they smoked tobacco frequently, costing the health care system over $\$ 4.4$ billion in health related illnesses. The aim of this study was to assess degrees of tobacco inhalation of smokers, non-smokers, ex-smokers, passive smokers and current smokers and their perceived quality of life and health.

\section{Methods}

The survey was conducted in the waiting room of two medical walk-in-clinics. The questionnaire comprised of four main aspects including age of the patient, identify themselves as a frequent smoker, a non-smoker (passive) who is regularly exposed to smoke, a past (ex-) smoker and a non-smoker who is not regularly exposed to tobacco smoke. Valid consent was obtained from the patients and patients under the age of 18 were not included in the study.

\section{Results}

A total of 387 patients completed the survey including 198 non-smokers, 83 passive smokers, 51 ex-smokers and 55 current smokers. The oldest group was the ex-smokers of a mean age of 52.6 years and the youngest was the smokers at 36.6 years $(\mathrm{p}<0.001)$. In between were the passive smokers at 43.6 years and non-smokers at 48.2 years $(\mathrm{p}=0.002)$.

\section{Conclusion}

This research found that current smokers have a persistently lower self-reported quality of life and health care

${ }^{1}$ Royal College of Surgeons In Ireland, Dublin, Ireland

Full list of author information is available at the end of the article as compared with the other groups. It is also evident that patients who quit smoking do not suffer a loss in quality of life nor health compared to non-smokers. In addition, this research indicates that smoking not only impacts a patient's health, but their overall QoL as well.

\section{Authors' details \\ ${ }^{1}$ Royal College of Surgeons In Ireland, Dublin, Ireland. ${ }^{2}$ Terry Fox Medical Centre, Mississauga, Ontario, Canada.}

Published: 27 October 2015

\section{doi:10.1186/1753-6561-9-S7-A18}

Cite this article as: Beshay and Beshay: The variation in the selfperceived quality of life and health care amongst smokers, passive smokers, ex-smokers and non-smokers in Canada. BMC Proceedings 2015 9(Suppl 7):A18.

\section{Submit your next manuscript to BioMed Central and take full advantage of: \\ - Convenient online submission \\ - Thorough peer review \\ - No space constraints or color figure charges \\ - Immediate publication on acceptance \\ - Inclusion in PubMed, CAS, Scopus and Google Scholar \\ - Research which is freely available for redistribution

